\title{
Equine poisoning by coffee husk (Coffea canephora) in northern Espírito Santo, Brazil
}

\author{
Arthur Zamprogno Benezoli', Sara Palmejani Gonçalves', Diogo Almeida Rondon', Luiz Alexandre Moscon', \\ Ana Lucia Schild ${ }^{2}$, Bethânia Souza Monteiro ${ }^{3}$, Franklin Riet-Correa ${ }^{4}$ \& Clairton Marcolongo-Pereira'
}

\begin{abstract}
Background: Brazil is the largest coffee (Coffea canephora and Coffea arabica) producer in the world, and Espírito Santo state is the second largest national producer of this commodity. Caffeine poisoning has been described in several animal and human species and is generally associated with accidental and/or intentional ingestion of caffeine-containing products. In horses, there are few reports in the literature about coffee poisoning, and most animals show clinical signs of excitability, involuntary muscle tremors, and chewing movements. Therefore, the objectives of the present study are to describe the clinical and epidemiological aspects of coffee (Coffea canephora) poisoning in horses in northern Espírito Santo, Brazil. Cases: Two horses from northern Espírito Santo presented with clinical signs of excessive sweating, reluctance to enter the trailer, muscle tremors, aggression, incoordination, constant tremors of the lips and tongue, chewing movements, and falling. Clinical signs began after the animals were confined in stalls containing coffee husk (Coffea canephora) for at least one week. After three days in the stall, the horse began to show clinical signs characterized by excessive sweating, reluctance to enter the trailer, aggression, and incoordination. On physical examination, there was marked dehydration, tachycardia $(120 \mathrm{bpm})$, tachypnea $(80 \mathrm{mpm})$ and a body temperature of $39.1^{\circ} \mathrm{C}$. In addition, the animal had cecum and ventral colon hypomotility. The horse was treated as soon as it was admitted to the hospital with a $10 \mathrm{ml} / \mathrm{h}$ intravenous drip of Ringer lactate solution; $100 \mathrm{ml}$ intravenous mercepton every 24 hours; $10 \mathrm{ml}$ intramuscular vitamin B1 every 24 hours, and $1.1 \mathrm{ml}$ intravenous acepromazine $1 \%$; when it showed increased excitability, it was treated for neurological signs and recovered four days after admission. The second animal was a three-year-old female Mangalarga Marchador horse, weighing $280 \mathrm{~kg}$. The animal was confined for 30 days with coffee husk bedding. The horse was fed $8 \mathrm{~kg}$ of corn silage and $4 \mathrm{~kg}$ of granulated feed per day. After two weeks in confinement, the animal began to show severe incoordination, extremely aggressive behavior, muscle tremors, constant tremors of the lips and tongue, chewing movements, excessive sweating, and falling.

Discussion: The diagnosis of coffee husk poisoning was based on the epidemiological and clinical characteristics of the disease. In Espírito Santo, it seems to be common to use coffee husk as bedding material for horses, mostly as a substitute for sand and wood shavings. In the properties where the animals lived, the coffee was planted to sell, and the remains from production, especially the husks, were used as bedding for the animals. It has been reported that when horses are placed in stalls with coffee husks, they tend to eat the husks spontaneously, resulting in intoxication. The clinical signs observed in this study were similar to those described in horses experimentally intoxicated by the plant. The neurological effects observed were due to the action of caffeine as an adenosine antagonist. The observed neurological clinical signs observed in these cases were nonspecific, and other disorders of the equine central nervous system, such as rabies and leukoencephalomalacia, should be considered in the differential diagnosis of coffee poisoning. Coffee husks should not be used as bedding for horses, as it can cause animal poisoning and death due to the excitatory effects of caffeine, which can lead to spontaneous falls and serious trauma.
\end{abstract}

Keywords: caffeine poisoning, nervous signs, horses, coffee husk, adenosine. 


\section{INTRODUCTION}

Brazil is the largest coffee (Coffea canephora and Coffea arabica) producer in the world, and Espírito Santo is the second largest national producer of this commodity, accounting for approximately $22 \%$ of all coffee production in the country. In the state, production is distributed over 435 thousand hectares, producing approximately 13 million bags per year [1]. In addition to using the fruit, coffee production residues, such as coffee husk and pulp, can be reused [3,5].

Caffeine poisoning has been described in several animal and human species and is generally associated with accidental and/or intentional ingestion of caffeine-containing products $[2,3,9,10]$. In dogs, there are reports of poisoning by accidental ingestion of supplements containing caffeine and ingestion of grains directly, as well as intentional poisoning. Intoxicated dogs present cardiorespiratory and neurological alterations, such as seizures, tachycardia, and tachypnea, and may progress to coma and death $[4,9]$. In horses, there are few studies on caffeine poisoning, and intoxicated animals show clinical signs, such as excitability, agitation, involuntary muscle tremors, chewing movements, constant lip and tongue tremors, excessive sweating and increased respiration and heart rates due to the effects of caffeine [3]. Therefore, the objectives of the present study are to describe the clinical and epidemiological aspects of coffee (Coffea canephora) poisoning in horses in northern Espírito Santo, Brazil.

\section{CASES}

Two horses from the municipality of São Mateus, northern Espírito Santo, presented at the Veterinary Hospital of University Center of Espírito Santo (UNESC). The first animal was a 4-year-old male Mangalarga Marchador horse that was raised under semi-intensive farming conditions. This animal was confined in a stall with coffee husk bedding for a week (Figure 1A). After three days in the stall, the horse began to show clinical signs characterized by excessive sweating, reluctance to enter the trailer, aggression, and incoordination. On physical examination, there was marked dehydration, tachycardia (120 beats per minute), tachypnea ( 80 movements per minute) and a body temperature of $39.1^{\circ} \mathrm{C}$. In addition, the animal had cecum and ventral colon hypomotility, a hematocrit increase of 59\% (reference value: $28-46 \%$ ), creatina quinase $(\mathrm{CK}) 826 \mathrm{u} / \mathrm{L}$ (reference value: $<270$ $\mathrm{u} / \mathrm{L}$ ), aspartato aminotransferase (AST) / transaminase glutâmico oxalacética (TGO) 652 u/L (reference value: $<230 \mathrm{u} / \mathrm{L}$ ) and urea $56 \mathrm{mg} / \mathrm{dL}$ (reference value: $21.4-51.3 \mathrm{mg} / \mathrm{dL}$ ). The horse was treated as soon as it was admitted to the hospital with a $10 \mathrm{~mL} / \mathrm{h}$ intravenous drip of Ringer lactate 1 solution; $100 \mathrm{~mL}$ intravenous mercepton $\left(\text { Mercepton }^{\circledR}\right)^{2}$ every $24 \mathrm{~h} ; 10$ $\mathrm{ml}$ intramuscular vitamin B1 (Monovin B $\left.1^{\circledR}\right)^{2}$ every $24 \mathrm{~h}$, and $1.1 \mathrm{~mL}$ intravenous acepromazine (Acepran $\left.1,0 \%{ }^{\circledR}\right)^{3}$; when it showed increased excitability, it was treated for neurological signs and recovered four days after admission.

The second animal was a 3-year-old, female Mangalarga Marchador horse, weighing $280 \mathrm{~kg}$. The animal was confined for 30 days with coffee husk bedding. The horse was fed $8 \mathrm{~kg}$ of corn silage and $4 \mathrm{~kg}$ of granulated feed per day. After two weeks in confinement, the animal began to show severe incoordination, extremely aggressive behavior, muscle tremors, constant tremors of the lips and tongue, chewing movements (Figure 1B), excessive sweating, and falling. Physical examination showed $9 \%$ dehydration, tachycardia ( 90 beats per minute), tachypnea (110 movements per minute), normal bowel movements, a body temperature of $38.6^{\circ} \mathrm{C}$, and excessive sweating, as well as a hematocrit level of $57 \%$ (reference value: 28 - 46\%), CK $721 \mathrm{mg} / \mathrm{dL}$ (reference value: $<270 \mathrm{mg}$ / dL), AST / TGO $428 \mathrm{u} / \mathrm{L}$ (reference value: $<230 \mathrm{u} / \mathrm{L}$ ) and urea $61 \mathrm{mg} / \mathrm{dL}$ (reference value: $21.4-51.3 \mathrm{mg}$ / $\mathrm{dL})$. There was no remission of the condition, and the animal died due to head injury.

\section{DISCUSSION}

The diagnosis of coffee husk poisoning was based on the epidemiological and clinical characteristic of the disease. In Espírito Santo, it seems to be common to use coffee husks as bedding material for horses, mostly as a substitute for sand and wood shavings. In the properties where the animals lived, the coffee was planted to sell, and the remains from production, especially the husks, were used as bedding for the animals. It has been reported that when horses are placed in stalls with coffee husks, they tend to eat the plant spontaneously, resulting in intoxication [3].

The clinical signs observed in this study were similar to those described in horses experimentally intoxicated by the plant [3]. The neurological effects observed were due to the action of caffeine as an 


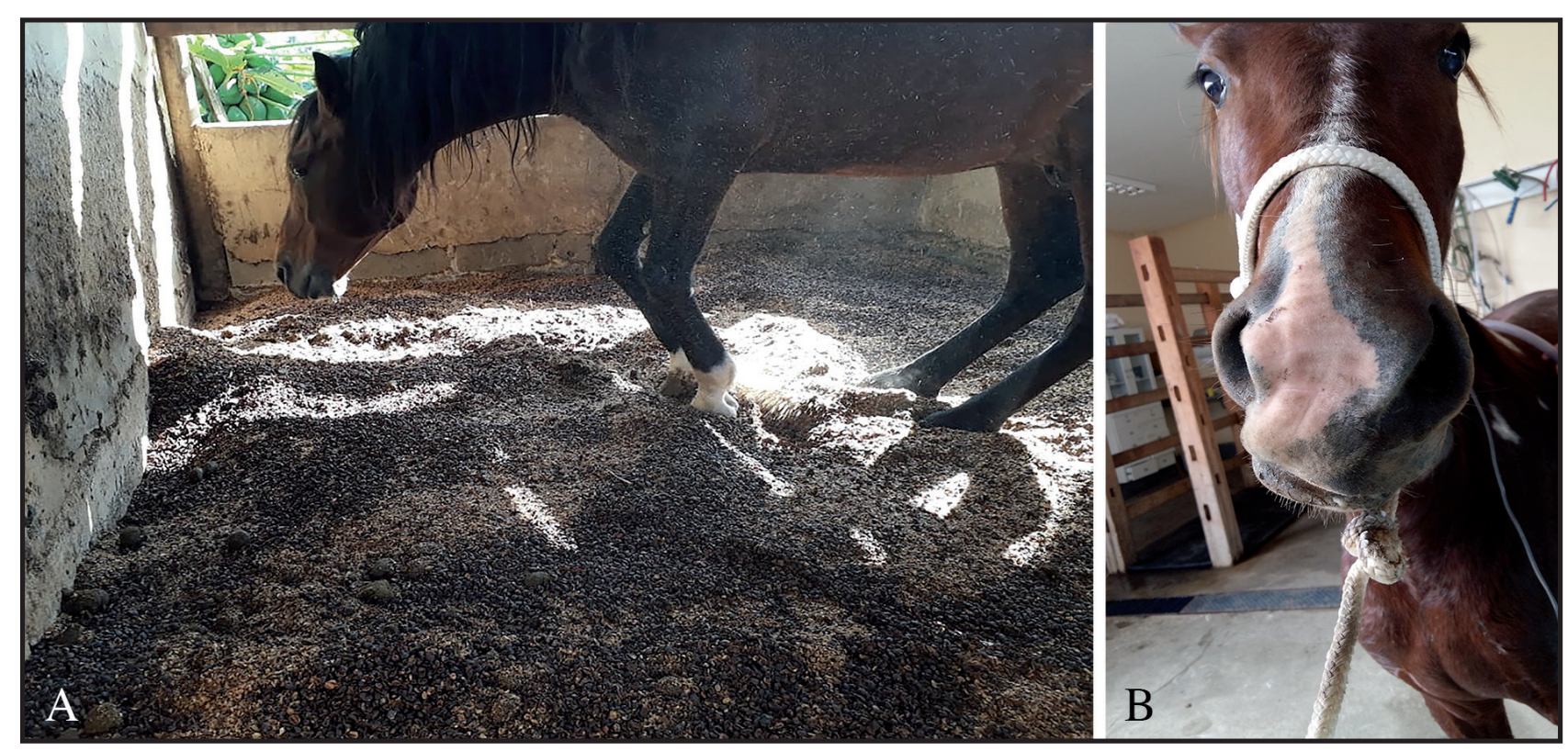

Figure 1. Equine poisoning by coffee husk (Coffea canephora). A- Horse confined in a stall with coffee husk bedding. B- Horse showing chewing movements and flaring nostrils.

Additional file 1. Equine poisoning by coffee husk (Coffea canephora). Horse intoxicated showing excitability, restlessness, constant movement of the lips (chewing movements), and flaring nostrils [https://youtu.be/devvht_YFuE].

adenosine antagonist. Caffeine binds to adenosine receptors and blocks the inhibitory effects of adenosine. This blockage leads to excitatory action in the smooth muscle, central nervous system, respiratory tract and gastrointestinal tract [8]. In addition, caffeine may affect catecholamine release $[4,6]$, which would explain the observed hematological and biochemical changes. Coffea canephora has the highest content of caffeine than other Coffea species [7], which may have contributed in exacerbation of clinical and haematological signs observed.

The neurological clinical signs observed in these cases were nonspecific, and other disorders of the equine central nervous system, such as rabies and leukoencephalomalacia, should be considered in the differential diagnosis of coffee poisoning. However, the animals were vaccinated for rabies and received no food containing moldy corn or moldy corn products.
In this study, one of the animals died during the intoxication period. The death was due to a head injury due to an abrupt fall caused by coffee husk intoxication.

Coffee husks should not be used as bedding for horses because they can cause animal poisoning and death due to the excitatory effects of caffeine, which can lead to spontaneous falls and serious trauma.

\section{MANUFACTURERS}

${ }^{1}$ JP Indústria Farmacêutica S.A. Ribeirão Preto, SP, Brazil.

${ }^{2}$ Laboratório Bravet Ltda. Engenho Novo, RJ, Brazil.

${ }^{3}$ Vetnil Industria e Comércio de Produtos Veterinários Ltda. Louveira, SP, Brazil.

Funding. This work was supported by grants from FAPES.

Declaration of interest. The authors report no conflicts of interest. The authors alone are responsible for the content and writing of the paper.

\section{REFERENCES}

1 Brainer M.S.C.P. 2018. Panorama Setorial do Café. Caderno Setorial ETENE. 48(3): 1-15.

2 Cappelletti S., Piacentino D., Fineschi V., Frati P., Cipolloni L. \& Aromatario M. 2018. Caffeine-Related Deaths: Manner of Deaths and Categories at Risk. Nutrients. 10(611): 1-13.

3 Delfiol D.J.Z., Oliveira Filho J.P., Casalecchi F.L., Kievitsbosch T., Hussni C.A., Riet-Correa F., Araujo Jr. J.P. \& Borges A.S. 2012. Equine poisoning by coffee husk (Coffea arabica L.). BMC Veterinary Research. 8(4): 1-8.

4 Hensel M., Pashmakova M. \& Porter B.F. 2017. Fatal caffeine intoxication in a dog. Brazilian Journal of Veterinary Pathology. 10(2): 65-68. 
5 Lima L.K.S., Santos C.C., Moura M.C.F., Dutra A.S. \& Oliveira Filho A.F. 2014. Utilização de Resíduo Oriundo da Torrefação do Café na Agricultura em Substituição a Adubação Convencional. Agropecuária Científica no Semiárido. 10(1): 14-19.

6 Nehlig A., Daval J.L. \& Debry G. 1992. Caffeine and the central nervous: mechanisms of action, biochemical, metabolic and psychostimulant effects. Brain Research Reviews. 17: 139-170.

7 Perrois C., Strickler S.R., Mathieu G., Lepelley M., Bedon L., Michaux S., Husson J., Mueller L. \& Privat I. 2015. Differential regulation of caffeine metabolism in Coffea arabica (Arabica) and Coffea canephora (Robusta). Planta. 241: 179-191

8 Queiroz Neto A., Zamur G., Carregaro A.B., Mataqueiro M.I., Salvadori M.C., Azevedo C.P., Harkins J.D. \& Tobin T. 2001. Effects of caffeine on locomotor activity of horses: Determination of the no-effect threshold. Journal of Applied Toxicology. 21: 229-234.

9 Tawde S.N., Puschner B., Albin T., Stump S. \& Poppenga R.H. 2012. Death by Caffeine: Presumptive Malicious Poisoning of a Dog by Incorporation in Ground Meat. Journal of Medical Toxicology. 8: 436-440.

10 Troxel M.T. \& Poppenga R.H. 2005. Kentucky Coffee Tree Intoxication in a Dog with Cerebellovestibular Signs, Bradycardia, Hypotension, and Hypoglycemia. Journal of Veterinary Internal Medicine. 19: 599-601. 